\title{
Inoculant Effects on Alfalfa Silage: Fermentation Products and Nutritive Value
}

\author{
I. Filya, ${ }^{\star}$ R. E. Muck, $\dagger^{1}$ and F. E. Contreras-Goveał \\ *Department of Animal Science, Faculty of Agriculture, Uludag University, 16059 Bursa, Turkey \\ †USDA, Agricultural Research Service, U.S. Dairy Forage Research Center, Madison, WI 53706 \\ ‡Department of Agronomy, University of Wisconsin, Madison 53706
}

\begin{abstract}
The effect of 14 microbial inoculants on the fermentation and nutritive value of alfalfa silages was studied under laboratory conditions. The first cut (477 g of dry matter $/ \mathrm{kg}$ ) and second cut (393 $\mathrm{g}$ of dry matter $/ \mathrm{kg}$ ) of a second-year alfalfa stand were ensiled in 2 trials. In both trials alfalfa was harvested with standard field equipment. All inoculants were applied at $1.0 \times 10^{6} \mathrm{cfu} / \mathrm{g}$ of crop. Uninoculated silages served as controls. After inoculants were added, the chopped forages were ensiled in 1.0- and 0.5-L anaerobic glass jars, respectively, at a density of $500 \mathrm{~g} / \mathrm{L}$. Each trial had 15 treatments (uninoculated control and 14 inoculants), with 4 silos per treatment. Silos were stored for a minimum of $30 \mathrm{~d}$ at room temperature $\left(\sim 22^{\circ} \mathrm{C}\right)$. In first-cut silage, all inoculants but one reduced $\mathrm{pH}$ relative to the uninoculated control, and all but 2 of the homofermentative strains shifted fermentation toward lactic acid. In second-cut silage, the epiphytic lactic acid bacterial population was $2.7 \times 10^{7}$ cfu/g, and only commercial inoculants produced significant shifts in fermentation. Overall, microbial inoculants generally had a positive effect on alfalfa silage characteristics in terms of lower $\mathrm{pH}$ and shifting fermentation toward lactic acid with homofermentative lactic acid bacteria or toward acetic acid with heterofermentative lactic acid bacteria, Lactobacillus buchneri. These effects were stronger in the commercial products tested. In spite of the positive effects on silage fermentation, 48 -h in vitro true DM digestibility was not improved by inoculation with lactic acid bacteria.
\end{abstract}

Key words: alfalfa, lactic acid bacteria, nutritive value, silage

\section{INTRODUCTION}

Inoculants are the most common biological additives used in silage preservation in the United States and

Received December 21, 2006.

Accepted May 2, 2007.

${ }^{1}$ Corresponding author: richard.muck@ars.usda.gov
Europe. These products have selected strains of homofermentative lactic acid bacteria (LAB), such as Lactobacillus plantarum, Enterococcus faecium, and Pediococcus spp. When used, such inoculants often result in a faster decrease in $\mathrm{pH}$, lower final $\mathrm{pH}$ values, higher lactate:acetate ratios, lower ethanol and ammonia nitrogen, and a 1 to $2 \%$ improvement in DM recovery (Weinberg and Muck, 1996). Recently, a heterofermentative LAB inoculant species, Lactobacillus buchneri, has become available commercially and produces high concentrations of acetic acid in silage that inhibit fungi and thus preserve silages susceptible to spoilage upon exposure to air (Weinberg et al., 2002; Filya, 2003a,b). Although the 2 types of inoculants take different approaches to directing fermentation in the silo, the principal goal of both is to preserve as much of the nutritive value of the crop at harvest as possible for the livestock consuming the resulting silage.

Although inoculants have been used for several decades, there are still unanswered questions about the interaction of inoculant $\mathrm{LAB}$ with other microorganisms and how this interaction drives fermentation and affects utilization of the silage by animals (Weinberg and Muck, 1996). Inoculants do not consistently improve silage fermentation or animal performance characteristics such as intake, feed efficiency, rate of gain, or milk production (Weinberg and Muck, 1996; Kung et al., 2003). In part, this may be due to characteristics of the crop at harvest: epiphytic LAB population, sugar availability, and plant DM concentration. For example, when the epiphytic LAB population is sufficiently greater than the level of $\mathrm{LAB}$ applied to the crop, the inoculant LAB can be overwhelmed and not significantly affect fermentation (Muck, 1989). However, variation in the results of inoculant studies may be due to the efficacy of the inoculant strains. This has been most clearly illustrated in occasional animal trials in which inoculants have had no significant effect on silage $\mathrm{pH}$ or fermentation products but the inoculated silages increased milk production or gain (Weinberg and Muck, 1996). Because the crop and its epiphytic microbial populations affect the results of inoculant trials, the relative efficacy of various inocu- 
Table 1. Inoculants used in the trials

\begin{tabular}{lll}
\hline Number $^{1}$ & \multicolumn{1}{c}{ Inoculant } & \multicolumn{1}{c}{ Source } \\
\hline 1 & Lactobacillus buchneri (Pioneer 11A44) & Pioneer Hi-Bred International Inc., Des Moines, IA \\
2 & L. buchneri (Biotal) & Biotal Canada Limited, Calgary, Alberta, Canada \\
3 & Lactobacillus plantarum and Enterococcus faecium (Pioneer 1174) & Pioneer Hi-Bred International Inc., Des Moines, IA \\
4 & L. plantarum and Pediococcus cerevisiae (Biomate LP/PC) & Chr. Hansen Biosystems, Milwaukee, WI \\
5 & L. plantarum (Biomax5) & Chr. Hansen Biosystems, Milwaukee, WI \\
6 & Pediococcus pentosaceus and Propionibacterium jensenii (Biotal Plus) & Biotal Canada Limited, Calgary, Alberta, Canada \\
7 & E. faecium, L. plantarum, and Pediococcus spp. (H/M Plus) & Medipharm USA, Des Moines, IA \\
8 & L. plantarum MTD1 (Ecosyl) & Ecosyl, Yorkshire, UK \\
9 & E. faecium C (Agri-King) & Agri-King, Fulton, IL \\
10 & E. faecium Q (Agri-King) & Agri-King, Fulton, IL \\
11 & Lactobacillus pentosus (Agri-King) & Agri-King, Fulton, IL \\
12 & L. plantarum (Agri-King) & Agri-King, Fulton, IL \\
13 & P. pentosaceus (Agri-King) & Agri-King, Fulton, IL \\
14 & P. pentosaceus (Ecosyl) & Ecosyl, Yorkshire, UK \\
\hline
\end{tabular}

${ }^{1}$ Inoculants 1 to 8 are commercially marketed.

lants can be measured accurately only by head-to-head comparisons on the same forage. A wide head-to-head comparison may also help reveal whether there are substantial or consistent inoculant effects on the silage characteristics that are typically measured to develop livestock rations.

The objective of this study was to test a wide variety of inoculant LAB on the ensiling of alfalfa and to determine the effects on silage fermentation, nutritive value, and rumen in vitro fermentation. This paper reports solely on the effects on silage fermentation and standard measures of nutritive value. Two subsequent papers address the effects on rumen in vitro fermentation [Muck et al., 2007; unpublished manuscript of the authors and D. R. Mertens, and P. J. Weimer (both at USDA, ARS, US Dairy Forage Research Center, Madison, WI)].

\section{MATERIALS AND METHODS}

\section{Mini Silo Experiments}

In 2003, alfalfa was ensiled in 2 trials (first cut, 477 $\mathrm{g}$ of DM/kg; second cut, $393 \mathrm{~g}$ of DM/kg) on June 9 and July 2 , respectively. In both trials, alfalfa was harvested with standard field equipment (mower-conditioner, forage harvester, 10-mm theoretical length of cut) without inoculation. The chopped alfalfa was ensiled in 1.0- and 0.5-L anaerobic glass jars (Weck, Wher-Oftlingen, Germany), respectively, at a density of $500 \mathrm{~g} / \mathrm{L}$. Each trial had 15 treatments (uninoculated control and 14 inoculants), with 4 silos per treatment. Eight inoculants were commercial products (inoculants 1 to 8; Table 1); the others were single strains provided by 2 companies. All inoculants were applied at a rate of $1.0 \times 10^{6} \mathrm{cfu} / \mathrm{g}$ of crop (not label rates) to help ensure domination of fermentation. All inoculants were diluted with distilled water so that they were applied at the same rate $(10 \mathrm{~g}$ of solution $/ \mathrm{kg}$ of crop). The control received $10 \mathrm{~g}$ of water/ $\mathrm{kg}$ of crop. The amount of chopped alfalfa for a given silo was weighed, sprayed with the appropriate inoculant solution with a plant sprayer (one sprayer for each treatment), mixed by hand, and then placed into the silo by hand with periodic tamping. Equipment coming into contact with treated alfalfa was washed and wiped with ethanol between treatments to prevent cross-contamination. Over the course of ensiling for all treatments, 4 samples of untreated chopped alfalfa were taken for analysis of initial characteristics, and all inoculant solutions were analyzed for LAB counts. Silos were stored for 35 and $47 \mathrm{~d}$, respectively, at room temperature $\left(\sim 22^{\circ} \mathrm{C}\right)$.

\section{Analyses}

The untreated chopped alfalfa at ensiling and the silages at silo opening were analyzed for the same constituents, with the exception that fermentation products were determined only on silages. Duplicate samples (50 g) were taken for moisture determination by freeze-drying. After moisture determination, the duplicate freezedried samples were ground together to 1-mm particle size and analyzed for total nitrogen by a Leco FP-2000A nitrogen analyzer (Leco Corp., St. Joseph, MI) and for $\mathrm{NDF}, \mathrm{ADF}$, and acid detergent lignin (ADL) through the procedure of Robertson and Van Soest (1977) as modified by Hintz et al. (1995) to include sodium sulfite during refluxing. Hemicellulose (HC) concentration was estimated by the difference of NDF minus ADF, and cellulose concentration was estimated by the difference of $\mathrm{ADF}$ minus $\mathrm{ADL}$. In vitro true $\mathrm{DM}$ digestibility [IVTDMD, i.e., (initial DM fermented - undigested NDF residue at $48 \mathrm{~h}$ )/initial DM fermented] was determined by the in vitro procedure of Goering and Van Soest (1970), and water-soluble carbohydrates (WSC) were determined by the phenol sulfuric acid method (Dubois et al., 1956). Another portion of original sample $(20 \mathrm{~g})$ was 
Table 2. Characteristics ( $\mathrm{g} / \mathrm{kg}$ of DM except as noted) of the fresh alfalfa at ensiling

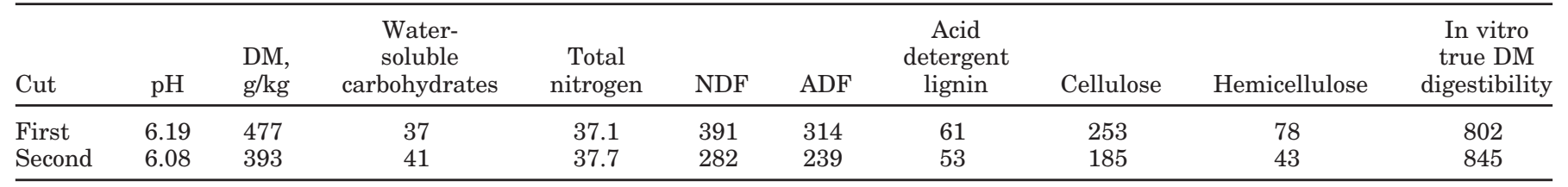

diluted 10:1 with autoclaved distilled water and blended in a 0.5-L Waring commercial laboratory high-speed blender for $30 \mathrm{~s}$. The diluted sample was enumerated immediately for acid-tolerant LAB by using Rogosa SL agar (Difco 0480, Becton Dickinson, Sparks, MD). After the diluted sample was subsampled for LAB, the remainder was filtered through 4 layers of cheesecloth, and $\mathrm{pH}$ was immediately measured on the filtrate. A $20-\mathrm{mL}$ aliquot of the filtrate was placed into a 50-mL polypropylene tube and centrifuged at $25,000 \times g$ for $25 \mathrm{~min}$. Liquid decanted from the centrifuge tube was frozen at $-20^{\circ} \mathrm{C}$ and used for measuring fermentation products. Fermentation products (lactate, acetate, propionate, butyrate, and ethanol) were determined by HPLC with a refractive index detector (Muck and Dickerson, 1988).

Because of differences in initial quality characteristics between harvests, statistical analysis was performed for each cut separately with the generalized linear model procedure of SAS (SAS Inst. Inc., Cary, NC). Differences among means were tested by Fisher's protected least significant difference, and significance was declared at $P<0.05$. Correlations among silage characteristics were determined using PROC CORR in SAS, with significance declared at $P<0.05$.

\section{RESULTS}

\section{Original Forage}

The first and second cuts of alfalfa were different in initial characteristics. First-cut alfalfa had higher DM, $\mathrm{NDF}, \mathrm{ADF}$, and ADL, and lower WSC and IVTDMD than second-cut alfalfa (Table 2). The IVTDMD values for both cuts were high compared with what might be expected in more common measurements of IVTDMD, such as that by Tilley and Terry (1963). The primary difference between the techniques is that our procedure is more effective in removing bacterial residues from in vitro fermentation (Van Soest et al., 1966), thus providing a more accurate estimate of the degree of digestion of the original silage. In first-cut alfalfa, the epiphytic LAB population at ensiling was $1.5 \times 10^{5} \mathrm{cfu} / \mathrm{g}$ and would have been expected to be overwhelmed by the inoculant LAB applied at $1.0 \times 10^{6} \mathrm{cfu} / \mathrm{g}$. In second-cut alfalfa, the epiphytic population $\left(2.7 \times 10^{7} \mathrm{cfu} / \mathrm{g}\right)$ at ensiling was more than 10 times higher than the inoculant applica- tion rates, providing a stiffer challenge for the added LAB.

\section{Fermentation Products}

The $\mathrm{pH}$, WSC, and organic acid concentrations of firstand second-cut alfalfa silages were different among treatments (Tables 3 and 4). In first-cut silage, all inoculants except $E$. faecium $\mathrm{C}$ reduced $\mathrm{pH}$ relative to that of the control (Table 3). The commercial homofermentative inoculants produced the largest reductions in $\mathrm{pH}$, whereas the 2 commercial heterofermentative ( $L$. buchneri) inoculants produced the smallest reductions, as might be expected. In second-cut silage, the only treatments lowering $\mathrm{pH}$ values more than the control were 5 of the 6 commercial homofermentative inoculants. The L. buchneri inoculants had the highest $\mathrm{pH}$ values.

Fermentation products in both cuts were limited to 3 principal products: lactate, acetate, and ethanol (Tables 3 and 4). Propionate and butyrate concentrations were below detectable concentrations $(0.1 \mathrm{~g} / \mathrm{kg}$ of DM). In firstcut alfalfa silage, the inoculated treatments produced from 2.5 to $106 \%$ greater lactate concentrations than the uninoculated treatment (Table 3). In addition, alfalfa inoculated with Lactobacillus pentosus, the 2 strains of L. buchneri, E. faecium C, E. faecium Q, the combination of $L$. plantarum and $E$. faecium, and $L$. plantarum MTD1 had 15 to $259 \%$ greater acetate concentrations than the uninoculated control. Even with these increases in acetate, the only treated silages in which the lactate:acetate ratios were lower than the uninoculated control (2.88) were $L$. pentosus (2.08), E. faecium C (2.39), and the $2 L$. buchneri $(2.21,2.40)$ strains. The lactate:acetate ratios ranged from 4.46 to 11.71 in the other treatments. Alfalfa silages inoculated with both $L$. buchneri strains and $E$. faecium $\mathrm{Q}$ had higher ethanol concentrations than the control and other LAB-inoculated alfalfa silages.

In second-cut alfalfa silage, the uninoculated silage had a greater lactate concentration than all but 2 inoculated alfalfa silages $(P<0.05$; Table 4$)$. Alfalfa silages inoculated with both $L$. buchneri strains and $L$. pentosus had higher acetate and ethanol concentrations than the control and other LAB-inoculated alfalfa silages $(P<$ 0.05 ). These 3 inoculants were the only ones to produce lower lactate:acetate ratios (1.73 to 2.74 ) compared with 
Table 3. Fermentation characteristics ( $\mathrm{g} / \mathrm{kg}$ of DM except as noted) of the first-cut alfalfa silages

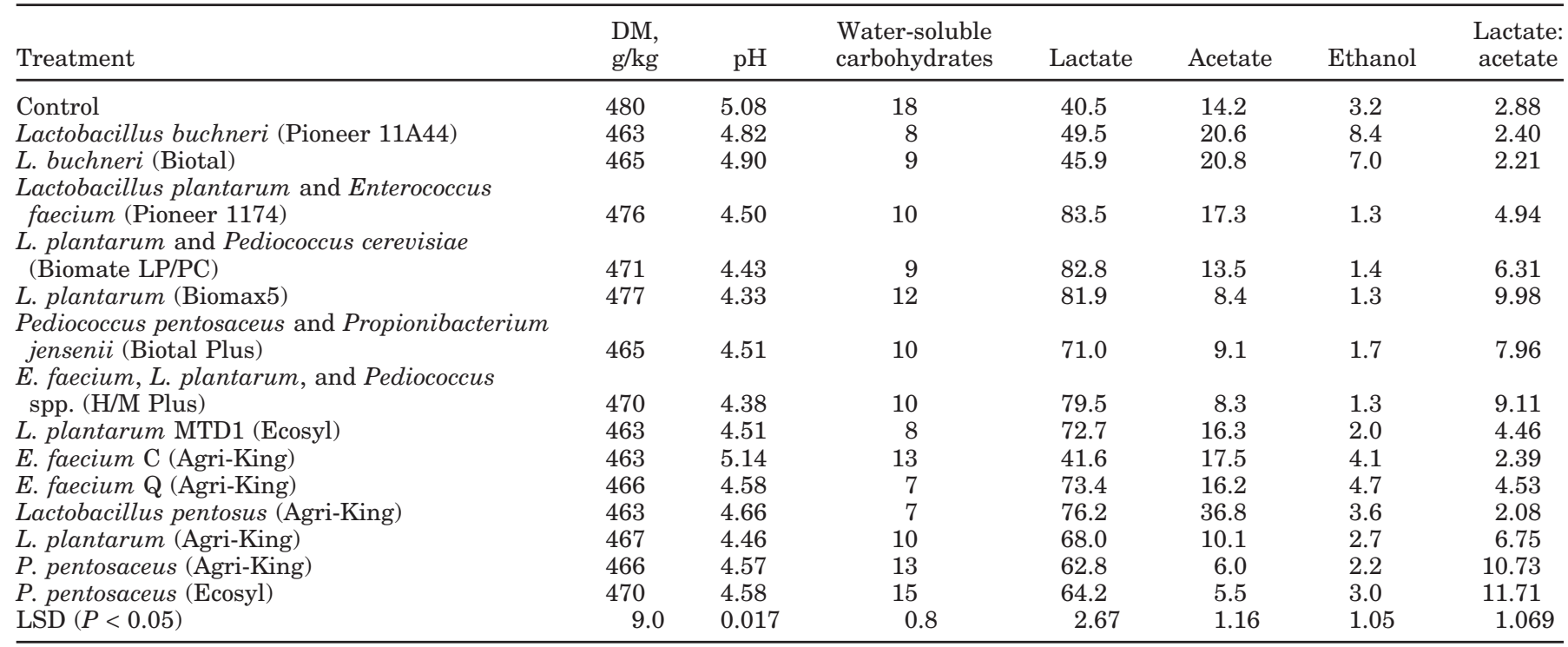

that of the control (2.98). This ratio ranged from 2.99 to 6.12 for the other inoculated silages.

The WSC remaining after fermentation in first-cut silage were significantly $(P<0.05)$ higher in the uninoculated control silage than in all other treatments (Table 3 ). The lowest WSC concentrations were in silages treated with $L$. pentosus, E. faecium Q, and the $2 L$. buchneri strains. In second-cut silage, the WSC concentration in the control was in the middle of the range for all treatments (Table 4). The lowest concentrations occurred in the L. buchneri treatments, and the highest were in 2 of the commercial inoculant treatments and the $2 E$. faecium treatments.

\section{Nutritive Characteristics}

On average, NDF, ADF, and ADL concentrations of the silages in both cuts (Tables 5 and 6) were higher than their respective values at ensiling (Table 2). Losses of DM from fermentation and respiration preferentially come from utilization of sugars by microorganisms (Pahlow et al., 2003), so such increases in the concentrations of cell wall fractions would be expected. However, the concentrations of polysaccharides in the cell wall varied by category. Cellulose concentrations in silages were, on average, higher than those in the unensiled alfalfa, whereas HC concentrations in the silages were numeri-

Table 4. Fermentation characteristics (g/kg of DM except as noted) of the second-cut alfalfa silages

\begin{tabular}{|c|c|c|c|c|c|c|c|}
\hline Treatment & $\begin{array}{l}\mathrm{DM}, \\
\mathrm{g} / \mathrm{kg}\end{array}$ & $\mathrm{pH}$ & $\begin{array}{l}\text { Water-soluble } \\
\text { carbohydrates }\end{array}$ & Lactate & Acetate & Ethanol & $\begin{array}{l}\text { Lactate: } \\
\text { acetate }\end{array}$ \\
\hline Control & 368 & 4.42 & 6.8 & 86.5 & 29.0 & 4.5 & 2.98 \\
\hline Lactobacillus buchneri (Pioneer 11A44) & 381 & 4.64 & 4.2 & 61.5 & 35.5 & 8.7 & 1.73 \\
\hline \multicolumn{8}{|l|}{ Lactobacillus plantarum and Enterococcus faecium } \\
\hline (Pioneer 1174) & 377 & 4.34 & 5.5 & 81.3 & 18.4 & 3.4 & 4.44 \\
\hline L. plantarum and Pediococcus cerevisiae (Biomate LP/PC) & 378 & 4.40 & 5.5 & 78.3 & 20.6 & 3.7 & 3.81 \\
\hline (Biotal Plus) & 372 & 4.42 & 8.8 & 79.0 & 21.0 & 4.6 & 3.78 \\
\hline E. faecium, L. plantarum, and Pediococcus spp. (H/M Plus) & 379 & 4.32 & 10.8 & 80.4 & 13.1 & 4.4 & 6.12 \\
\hline L. plantarum MTD1 (Ecosyl) & 363 & 4.40 & 5.7 & 80.5 & 19.0 & 4.1 & 4.28 \\
\hline E. faecium C (Agri-King) & 364 & 4.47 & 8.1 & 84.6 & 28.7 & 4.6 & 2.99 \\
\hline E. faecium Q (Agri-King) & 385 & 4.44 & 8.0 & 78.2 & 22.6 & 4.6 & 3.46 \\
\hline Lactobacillus pentosus (Agri-King) & 365 & 4.46 & 6.7 & 86.0 & 31.7 & 5.5 & 2.74 \\
\hline L. plantarum (Agri-King) & 367 & 4.42 & 7.7 & 80.0 & 20.9 & 6.1 & 3.84 \\
\hline
\end{tabular}


Table 5. Cell wall components, total nitrogen (TN), and in vitro true DM digestibility (IVTDMD) (g/kg of DM) of first-cut alfalfa silages

\begin{tabular}{|c|c|c|c|c|c|c|c|}
\hline Treatment & NDF & $\mathrm{ADF}$ & $\begin{array}{c}\text { Acid } \\
\text { detergent } \\
\text { lignin }\end{array}$ & Hemicellulose & Cellulose & $\mathrm{TN}$ & IVTDML \\
\hline Control & 419 & 342 & 78 & 78 & 264 & 34.5 & 766 \\
\hline L. buchneri (Biotal) & 442 & 354 & 77 & 88 & 276 & 34.0 & 760 \\
\hline \multicolumn{8}{|l|}{ Lactobacillus plantarum and Enterococcus faecium } \\
\hline (Pioneer 1174) & 436 & 356 & 79 & 80 & 277 & 35.1 & 767 \\
\hline L. plantarum and Pediococcus cerevisiae (Biomate LP/PC) & 420 & 352 & 76 & 67 & 277 & 35.1 & 769 \\
\hline (Biotal Plus) & 419 & 354 & 81 & 65 & 273 & 35.3 & 769 \\
\hline E. faecium, L. plantarum, and Pediococcus spp. (H/M Plus) & 421 & 350 & 75 & 70 & 276 & 34.8 & 773 \\
\hline L. plantarum MTD1 (Ecosyl) & 434 & 361 & 82 & 73 & 279 & 34.3 & 764 \\
\hline E. faecium C (Agri-King) & 391 & 330 & 71 & 61 & 259 & 35.9 & 778 \\
\hline E. faecium Q (Agri-King) & 424 & 354 & 81 & 71 & 273 & 35.0 & 762 \\
\hline Lactobacillus pentosus (Agri-King) & 421 & 346 & 78 & 75 & 267 & 37.0 & 766 \\
\hline L. plantarum (Agri-King) & 404 & 335 & 73 & 70 & 261 & 35.0 & 773 \\
\hline
\end{tabular}

cally lower, on average, than those prior to ensiling. A reduction in $\mathrm{HC}$ during ensiling has been reported in various forages, including alfalfa (Rooke and Hatfield, 2003), and in alfalfa the reduction in $\mathrm{HC}$ appears to be the result of acid hydrolysis of arabinosyl side branches from the main HC backbone (Jones et al., 1992).

In both cuts, some significant differences in cell wall constituents by treatment were observed. In first-cut silage, significant differences were observed in NDF, $\mathrm{ADF}, \mathrm{ADL}$, and cellulose (Table 5). In second-cut silage, NDF, ADL, and HC differed by treatment (Table 6). In first-cut silage, the concentrations of $\mathrm{NDF}, \mathrm{ADF}, \mathrm{ADL}$,
$\mathrm{HC}$, and cellulose of the control were in the middle of the ranges for each constituent. As a result, although there were inoculant treatments that were significantly different from one another, there were few instances in which an inoculated treatment was different from the uninoculated control. The exceptions were the low NDF and $\mathrm{ADL}$ concentrations for E. faecium $\mathrm{C}$ and the high $\mathrm{ADF}$ and cellulose values for Biomax5 and L. plantarum MTD1. In second-cut silage, the control had the highest $\mathrm{ADL}$ and $\mathrm{HC}$ concentrations, a high $\mathrm{NDF}$, and moderate levels of ADF and cellulose. Similar to first-cut silage, the $E$. faecium $\mathrm{C}$ treatment had significantly lower NDF

Table 6. Cell wall components, total nitrogen (TN) and in vitro true DM digestibility (IVTDMD) (g/kg of DM) of second-cut alfalfa silages

\begin{tabular}{|c|c|c|c|c|c|c|c|}
\hline Treatment & $\mathrm{NDF}$ & $\mathrm{ADF}$ & $\begin{array}{c}\text { Acid } \\
\text { detergent } \\
\text { lignin }\end{array}$ & Hemicellulose & Cellulose & $\mathrm{TN}$ & IVTDMD \\
\hline Control & 307 & 258 & 62 & 49 & 196 & 38.1 & 873 \\
\hline L. buchneri (Biotal) & 314 & 260 & 56 & 54 & 204 & 39.2 & 835 \\
\hline \multicolumn{8}{|l|}{ Lactobacillus plantarum and Enterococcus faecium } \\
\hline (Pioneer 1174) & 293 & 253 & 58 & 41 & 195 & 38.4 & 875 \\
\hline \multicolumn{8}{|l|}{ Pediococcus pentosaceus and Propionibacterium jensenii } \\
\hline (Biotal Plus) & 291 & 259 & 54 & 32 & 205 & 39.1 & 851 \\
\hline E. faecium, L. plantarum, and Pediococcus spp. (H/M Plus) & 290 & 255 & 55 & 34 & 200 & 38.9 & 856 \\
\hline L. plantarum MTD1 (Ecosyl) & 292 & 255 & 53 & 37 & 202 & 39.5 & 849 \\
\hline E. faecium C (Agri-King) & 284 & 256 & 57 & 29 & 199 & 39.0 & 854 \\
\hline E. faecium Q (Agri-King) & 292 & 261 & 57 & 31 & 204 & 38.8 & 863 \\
\hline Lactobacillus pentosus (Agri-King) & 309 & 263 & 59 & 46 & 204 & 38.3 & 840 \\
\hline
\end{tabular}


and ADL concentrations than the control, as well as the lowest HC concentration. Enterococcus faecium Q had concentrations of those constituents similar to $E$. faecium C. Eight other inoculants had lower ADL values than the control. In addition to the $E$. faecium treatments, Biotal Plus and H/M Plus had lower HC values than the control.

Total nitrogen was affected by treatment in first-cut but not in second-cut silage (Tables 5 and 6). Few instances of significant differences in first-cut silage were found. Only the silage treated with $L$. pentosus had a total nitrogen value statistically different from the control.

In vitro true DM digestibility was significantly affected by treatment in second-cut but not in first-cut silage (Tables 5 and 6). In second-cut silage, IVTDMD was highest in Pioneer 1174, and the control had a value similar to that of Pioneer 1174. Seven inoculant treatments had IVTDMD values significantly lower than the uninoculated control: Biotal L. buchneri, Biomate LP/ PC, L. plantarum MTD1, L. pentosus, Agri-King L. plantarum, and the 2 Pediococcus strains.

\section{DISCUSSION}

In first-cut silage, conditions for an inoculant to improve silage fermentation were nearly ideal: a somewhat high $\mathrm{DM}$ content $(477 \mathrm{~g}$ of $\mathrm{DM} / \mathrm{kg}$ ) that would restrict normal fermentation (Muck et al., 2003), a limited WSC content, and an epiphytic LAB population lower than the applied rates of inoculant LAB. All inoculant treatments, except for $E$. faecium $\mathrm{C}$, reduced $\mathrm{pH}$ relative to the control. The greatest reduction in $\mathrm{pH}$ relative to the control was 0.75 , a substantial difference. Most inoculant LAB treatments produced silages with higher lactate:acetate ratios than the uninoculated control. The exceptions were the heterofermentative L. buchneri treatments and the 2 single homofermentative strains. Such shifts (lower $\mathrm{pH}$ and higher lactate:acetate ratios) in silage fermentation with homofermentative LAB are consistent with summaries of previous studies when such inoculants were successful (e.g., Weinberg and Muck, 1996; Muck and Kung, 1997; Kung et al., 2003). Among the 12 homofermentative inoculants, there were significant differences in $\mathrm{pH}$ and fermentation products. The 3 silages with the lowest $\mathrm{pH}$ values were produced by commercial inoculants, whereas the 2 highest lactate:acetate ratios were produced by the Pediococcus pentosaceus strains, not the commercial inoculants.

The second-cut trial provided a greater challenge for the inoculant LAB. The epiphytic LAB population was more than 10 times the application rates of the inoculant LAB. In addition, the uninoculated silage achieved a low $\mathrm{pH}(4.42)$ with a high lactic acid content $(86.5 \mathrm{~g} / \mathrm{kg}$ of
DM). Even with these challenges, all 8 of the commercial inoculant products produced significant shifts in $\mathrm{pH}$ or fermentation products, which indicated that they had affected the final outcome of silage fermentation. The $L$. buchneri treatments increased $\mathrm{pH}$ and shifted fermentation to acetic acid relative to the control, as expected with a heterolactic fermentation (Moon, 1983). Five of the 6 homofermentative commercial inoculants lowered $\mathrm{pH}$ relative to the control, and all 6 produced a more homofermentative fermentation (i.e., higher lactate:acetate ratio) even though producing less lactic acid than the control treatment. The 6 homofermentative single strains showed less evidence of affecting fermentation. The ability of the commercial inoculants to affect fermentation even when present at lower numbers than the epiphytic population has been observed previously. For example, Muck (1989) conducted 4 trials and found that the inoculant used (similar to the H/M Plus inoculant here) consistently improved silage fermentation when applied at $10 \%$ or more of the epiphytic population but had no significant effect when applied at less than $1 \%$ of the epiphytic population.

One might have expected, based on the fermentation results presented in Tables 3 and 4, that the inoculant treatments, particularly in first-cut silage, would have affected rumen in vitro fermentation. However, no effect on a 48-h IVTDMD measurement was observed in firstcut silage (Table 5). In second-cut silage, the control silage had the second highest IVTDMD and 7 inoculated treatments had IVTDMD values significantly lower than that of the control. The lack of a positive effect of inoculants on IVTDMD or other measures of potential digestibility has occurred in some studies. Muck and Kung (1997) found that fermentation was improved (i.e., reduced $\mathrm{pH}$, increased the lactate:acetate ratio, or both) by inoculants in more than $60 \%$ of trials published between 1990 and 1995, whereas DM digestibility (in vitro or in vivo) was increased in only $30 \%$ of the trials. Weinberg and Muck (1996), in their review, also reported instances in which fermentation was affected by an inoculant, whereas digestibility was not.

Within a trial, IVTDMD values of individual silos were generally negatively correlated with various fiber constituents. In first-cut silage, the highest correlation was with $\mathrm{ADF}(\mathrm{r}=-0.630)$. In second-cut silage, the highest correlation was with cellulose $(r=-0.376)$. Negative correlations with fiber components would be expected because the cell wall component of the silage is the least digestible fraction. Based on the reduction of NDF, $E$. faecium $\mathrm{C}$ should have had the greatest effect on IVTDMD. It had the highest IVTDMD numerically, although not significantly, in first-cut silage but had an IVTDMD similar to the mean in second-cut silage. The consistent reduction of $\mathrm{NDF}$ by $E$. faecium $\mathrm{C}$ was unex- 
pected because LAB are not known to have enzymes that break down structural carbohydrates (Rooke and Hatfield, 2003).

Most fermentation products and $\mathrm{pH}$ were not highly correlated with IVTDMD. However, there was a significant correlation $(P<0.03)$ between IVTDMD and ethanol $(\mathrm{r}=-0.292$ and -0.373 for first- and second-cut silage, respectively). Such a correlation might be expected. Ethanol production, whether by yeast or LAB, leads to carbon dioxide production and loss of digestible DM (McDonald et al., 1991).

Although positive effects of silage inoculants on IVTDMD were not observed in this study, it is still possible that these inoculated silages could affect animal performance via the rate of digestion or some other factor (Weinberg and Muck, 1996). In subsequent papers (Muck et al., 2007; unpublished paper of authors, D. R. Mertens, and P. J. Weimer) look at the rates and products of in vitro fermentation across the silages in these 2 trials.

\section{CONCLUSIONS}

Microbial inoculants generally had a positive effect on alfalfa silage characteristics in terms of lower $\mathrm{pH}$ and shifting fermentation toward lactic acid with homofermentative LAB or toward acetic acid with $L$. buchneri. These effects were stronger in the commercial products tested. However in both trials, 48-h IVTDMD was not increased by treatment of the crop with $\mathrm{LAB}$ at ensiling.

\section{ACKNOWLEDGMENTS}

The authors are grateful for the technical assistance of U. C. Hymes Fecht and help with analyses from S. Coleman.

\section{REFERENCES}

Dubois, M., K. A. Giles, J. K. Hamilton, P. A. Rebes, and F. Smith. 1956. Colorimetric method for determination of sugars and related substances. Anal. Chem. 28:350-356.

Filya, I. 2003a. The effect of Lactobacillus buchneri and L. plantarum on the fermentation, aerobic stability, and ruminal degradability of low dry matter corn and sorghum silages. J. Dairy Sci. 86:3575-3581.

Filya, I. 2003b. The effect of Lactobacillus buchneri, with or without homofermentative lactic acid bacteria, on the fermentation, aerobic stability, and ruminal degradability of wheat, sorghum, and maize silages. J. Appl. Microbiol. 95:1080-1086.

Goering, H. K., and P. J. Van Soest. 1970. Forage Fiber Analysis (Apparatus, Reagents, Procedures and Some Applications). Agricultural Handbook No. 379. US Government Printing Office, Washington, DC.

Hintz, R. W., D. R. Mertens, and K. A. Albrecht. 1995. Effects of sodium sulfite on recovery and composition of detergent fiber and lignin. J. AOAC 78:16-22.

Jones, B. A., R. D. Hatfield, and R. E. Muck. 1992. Effect of fermentation and bacterial inoculation on lucerne cell walls. J. Sci. Food Agric. 60:147-153.

Kung, L., Jr., M. R. Stokes, and C. J. Lin. 2003. Silage additives. Pages 305-360 in Silage Science and Technology. D. R. Buxton, R. E. Muck, and J. H. Harrison, ed. Am. Soc. Agron., Crop Sci. Soc. Am., Soil Sci. Soc. Am., Madison, WI.

McDonald, P., N. Henderson, and S. Heron. 1991. The Biochemistry of Silage. 2nd ed. Chalcombe, Marlow, UK.

Moon, N. J. 1983. Inhibition of the growth of acid tolerant yeasts by acetate, lactate and propionate and their synergistic mixtures. J. Appl. Bacteriol. 55:454-460.

Muck, R. E. 1989. Effect of inoculation level on alfalfa silage quality. Trans. ASAE 32:1153-1158.

Muck, R. E., and J. T. Dickerson. 1988. Storage temperature effects on proteolysis in alfalfa silage. Trans. ASAE 31:1005-1009.

Muck, R. E., I. Filya, and F. E. Contreras-Govea. 2007. Inoculant effects on alfalfa silage: In vitro gas and volatile fatty acid production. J. Dairy Sci. 90:5115-5125.

Muck, R. E., and L. Kung Jr. 1997. Effects of silage additives on ensiling. Pages 187-199 in Silage: Field to Feedbunk. NRAES-99. Northeast Reg. Agric. Eng. Serv., Ithaca, NY.

Muck, R. E., L. E. Moser, and R. E. Pitt. 2003. Postharvest factors affecting ensiling. Pages 251-304 in Silage Science and Technology. D. R. Buxton, R. E. Muck, and J. H. Harrison, ed. Am. Soc. Agron., Crop Sci. Soc. Am., Soil Sci. Soc. Am., Madison, WI.

Pahlow, G., R. E. Muck, F. Driehuis, S. J. W. H. Oude Elferink, and S. F. Spoelstra. 2003. Microbiology of ensiling. Pages 31-93 in Silage Science and Technology. D. R. Buxton, R. E. Muck, and J. H. Harrison, ed. Am. Soc. Agron., Crop Sci. Soc. Am., Soil Sci. Soc. Am., Madison, WI.

Robertson, J. B., and P. J. Van Soest. 1977. Dietary fibre estimation in concentrate feedstuffs. J. Anim. Sci. 45(Suppl.):254. (Abstr.)

Rooke, J. A., and R. D. Hatfield. 2003. Biochemistry of ensiling. Pages 95-139 in Silage Science and Technology. D. R. Buxton, R. E. Muck, and J. H. Harrison, ed. Am. Soc. Agron., Crop Sci. Soc. Am., Soil Sci. Soc. Am., Madison, WI.

Tilley, J. M. A., and R. A. Terry. 1963. A two stage technique for in vitro digestion of forage crops. J. Br. Grassl. Soc. 18:104-111.

Van Soest, P. J., R. H. Wine, and L. A. Moore. 1966. Estimation of the true digestibility of forages by the in vitro digestion of cell walls. Pages 438-441 in Proc. X Int. Grassl. Congr., Helsinki, Finland. A. G. G. Hill, ed. Valtioneuvoston Kirjapaino, Helsinki, Finland.

Weinberg, Z. G., G. Ashbell, Y. Hen, A. Azrieli, G. Szakacs, and I. Filya. 2002. Ensiling whole-crop wheat and corn in large containers with Lactobacillus plantarum and Lactobacillus buchneri. J. Ind. Microbiol. Biotechnol. 28:7-11.

Weinberg, Z. G., and R. E. Muck. 1996. New trends in development and use of inoculants for silage. FEMS Microbiol. Rev. 19:53-68. 